\title{
Endothelin-1 regulation of immediate early gene expression in cardiac myocytes: negative feedback regulation of interleukin 6 by Atf3 and Klf2
}

Article

Accepted Version

Clerk, A., Cullingford, T. E., Fuller, S. J., Giraldo, A. and Sugden, P. H. (2009) Endothelin-1 regulation of immediate early gene expression in cardiac myocytes: negative feedback regulation of interleukin 6 by Atf3 and Klf2. Advances in Enzyme Regulation, 49 (1). pp. 30-42. ISSN 0065-2571 doi: https://doi.org/10.1016/j.advenzreg.2008.12.007 Available at https://centaur.reading.ac.uk/30934/

It is advisable to refer to the publisher's version if you intend to cite from the work. See Guidance on citing.

To link to this article DOI: http://dx.doi.org/10.1016/j.advenzreg.2008.12.007

Publisher: Elsevier

All outputs in CentAUR are protected by Intellectual Property Rights law, including copyright law. Copyright and IPR is retained by the creators or other copyright holders. Terms and conditions for use of this material are defined in the End User Agreement. 


\section{www.reading.ac.uk/centaur}

\section{CentAUR}

Central Archive at the University of Reading

Reading's research outputs online 
Running title: Endothelin and immediate early genes

Endothelin-1 regulation of immediate early gene expression in cardiac myocytes: negative feedback regulation of interleukin 6 by Atf3 and Klf2.

Angela Clerk*, Timothy E. Cullingford, Stephen J. Fuller, Alejandro Giraldo, Samir Ounzain and Peter H. Sugden

NHLI Division (Cardiac Medicine Section), Faculty of Medicine, Imperial College London, Flowers Building, Armstrong Road, London SW7 2AZ, UK.

*Corresponding author. Tel.: +44 207594 3009; Fax: +44 207594 3419; E-mail address: a.clerk@imperial.ac.uk

\section{Introduction}

Activation of intracellular signalling pathways by endothelin-1.

Cardiac myocytes are terminally-differentiated cells which withdraw from the cell cycle soon after birth. Subsequent growth results from an increase in size of individual myocytes (i.e. hypertrophy) rather than an increase in cell number. Various stimuli promote cardiac myocyte hypertrophy including peptide growth factors which signal through receptor protein tyrosine kinases (e.g. platelet-derived growth factor, PDGF (Clerk et al., 2006)) and Gq protein-coupled receptor (GqPCR) agonists such as " -adrenergic agonists or endothelin-1 
(ET-1) (Sugden and Clerk, 1998). These promote both morphological changes (increase in cell size and myofibrillar content) and changes in gene expression [e.g. increased expression of immediate early genes (IEGs) including c-jun or c-fos] associated with the hypertrophic response (Sugden and Clerk, 1998; Clerk et al., 2007a).

In cardiac myocytes, ET-1 acts principally through $\mathrm{ET}_{\mathrm{A}}$ receptors. These couple through heterotrimeric Gq proteins leading to activation of phospholipase C\$ which promotes hydrolysis of phosphatidylinositol 4,5 bisphosphate to produce inositol 1,4,5 trisphosphate and diacylglycerol (DAG) (Clerk and Sugden, 1997). This leads to activation of DAG-responsive PKCs and, in cardiac myocytes, ET-1 particularly activates the novel PKC isoforms, nPKC* and nPKC, (Clerk et al., 1994). ET-1 also stimulates small G proteins, with increased GTP-loading of Ras, Rac1 and RhoA (Chiloeches et al., 1999; Clerk et al., 2001; Brown et al., 2006). All these events can be detected within the first 1 min after stimulation. Downstream of these very early signalling elements, mitogen-activated protein kinases (MAPKs) are activated and these include extracellular signal-regulated kinases 1/2 (ERK1/2), c-Jun N-terminal kinases (JNKs) and p38-MAPKs (Bogoyevitch et al., 1993; Bogoyevitch et al., 1994; Bogoyevitch et al., 1995; Clerk et al., 1998). Activation of all MAPKs is associated with hypertrophic growth of cardiac myocytes, but evidence from transgenic mice particularly implicates ERK1/2 in beneficial (compensated) cardiac hypertrophy (Sugden and Clerk, 1998; Bueno and Molkentin, 2002). Other cells also possess $\mathrm{ET}_{\mathrm{A}}$ receptors including fibroblasts and glioma cells. For example, in rat C6 glioblastoma cells as in cardiac myocytes, ET-1 activates phospholipase C\$, PKC, and ERK1/2 leading to upregulation of c-jun and c-fos (Yin et al., 9920; Ambar, Sokolovsky, 1993; Chen, 1993; Leach et al., 1999). In these cells, ET-1 promotes DNA synthesis and cell cycle progression rather than hypertrophy, and ET-1 may promote tumorigenic states (MacCumber et al., 1990; 
Shichiri et al., 1991; Clozel and Salloukh, 2005). The acute signalling events triggered by ET-1 presumably lead to the changes in gene/protein expression associated with cardiac myocyte hypertrophy or cell cycle progression in proliferating cells. However, activation of intracellular signalling elements such as PKC and ERK1/2 occurs rapidly and, at least in cardiac myocytes, this activation is transient. Thus, activation of ERK1/2 by ET-1 in cultured cardiac myocytes is maximal at $\sim 5$ min, returning almost to basal levels within $\sim 30$ min (Clerk et al., 1994; Clerk et al., 1996). How these early transient signals are propagated and lead to the phenotypic responses over many hours or even days is not often considered.

\section{Regulation of gene expression by ET-1.}

In any cellular response, activation of pre-existing transcription factors (TFs) downstream of intracellular signalling events leads to the increased expression IEGs. Because IEG expression is driven by pre-existing TFs, there is no requirement for de novo protein synthesis and the response is not inhibited by protein synthesis inhibitors such as cycloheximide. Some IEGs encode "structural" proteins such as ion channels or components of the cytoskeleton which directly influence the cellular phenotype. However, many IEGs constitute a "regulatory" component, encoding transcriptional regulators including TFs. At least some of the IEGs encode negative regulators of gene expression which feed back to limit the IEG response, whereas other combinations of TFs regulate downstream, secondphase gene expression. Since second phase genes require synthesis of IEG proteins, this phase of the response is inhibited by cycloheximide. In contrast, preventing the expression of a negative feedback protein by cycloheximide results in enhanced expression of IEG mRNAs. Potentially, second phase TFs regulate expression of third-phase genes further downstream, etc. (see Fig. 1 and (Clerk et al., 2007a)). As the response progresses, the 
proportion of "regulatory" to "structural" proteins declines as the new steady-state phenotype develops. Throughout this time, cells remain responsive to the environment although the response is probably modulated by changing expression of cell surface receptors and intracellular signalling components. The cells also influence the environment by producing extracellular matrix components and secreted factors which signal to other cells in the vicinity.

IEGs (e.g. c-fos, c-jun, egr1) are upregulated in cardiac myocyte hypertrophy (Dorn et al., 2003; Sugden and Clerk, 1998), and it is assumed that they regulate expression of hypertrophic genes including classical markers of hypertrophy (e.g. atrial natriuretic factor, ANF). However, our knowledge has previously been limited to a few established IEGs and it is not clear how the expression of these genes/proteins leads hypertrophy. To start to clarify these issues, we have been using microarrays to determine the changes in gene expression induced by ET-1 in primary cultures of neonatal rat ventricular cardiac myocytes (NRVMs) over the first $4 \mathrm{~h}$ (as the initial phases of the response develop) and to distinguish IEGs from downstream gene expression (Cullingford et al., 2008b). Our data demonstrate a multiphasic response consistent with the model described above and in Fig. 1. Early IEGs are induced within 30 min, with later IEGs appearing at 1 - $2 \mathrm{~h}$. Surprisingly, the earliest of the second phase genes are detected within $1 \mathrm{~h}$. At these early times, many of the genes are associated with transcriptional regulation or with intercellular or intracellular signalling and are not classically associated with hypertrophy. This indicates that this phase is an intermediate stage in the response. Several families of TFs were subject to regulation by ET-1 within the first hour, and these may be "master-switches" for downstream gene regulation. For example, there are significant changes in expression of many of the Krüppel-like factors (Klfs), suggesting that Klfs play a major role in the response (Cullingford et al., 2008a; 
Cullingford et al., 2008b). One example of a potential feedback inhibitor of IEG expression is activating transcription factor 3 (Atf3) which is implicated in downregulation of expression of interleukin 6 (IL6) in the context of endotoxin-induced inflammation (Gilchrist et al., 2006). Here, we present data for the regulation of three IEGs which are responsive to ET-1 in cardiac myocytes: Atf3, Klf2 and IL6.

\section{Materials and methods}

Preparation of neonatal cardiac myocytes and adenoviral infection

Myocytes were dissociated from the ventricles of neonatal Sprague-Dawley rat hearts using collagenase and pancreatin as previously described (Iwaki et al., 1990; Bogoyevitch et al., 1995). Non-myocytes were removed by pre-plating onto uncoated tissue culture dishes (30 min, 37/C). The (non-adherent) cardiac myocytes were collected and plated in serumcontaining medium at a density of $1.4 \times 10^{3}$ cells $/ \mathrm{mm}^{2}$ on Primaria tissue culture dishes precoated with $1 \%(\mathrm{w} / \mathrm{v})$ gelatin. After $18 \mathrm{~h}$, serum was withdrawn for $24 \mathrm{~h}$ prior to use. Agonists were added directly to the tissue culture medium. For adenoviral infection, cardiac myocytes were serum-starved for $4 \mathrm{~h}$ before adding $200: \mathrm{l}$ of virus stock in PBS to the medium. Cardiac myocytes were incubated for a further $48 \mathrm{~h}$ before experimentation.

Semi-quantitative and quantitative reverse transcriptase polymerase chain reaction (RTPCR)

RNA was prepared and semi-quantitative RT-PCR performed as previously described (Clerk et al., 2007b), using 100 pmol forward and reverse primers as follows: Atf3 (accession no. NM_012912): forward 5'- GCTGCCAAGTGTCGAAACAAG -3', reverse 
5'-CAGTTTTCCAATGGCTTCAGG-3', 388 bp product; IL6 (accession no. NM_012589) : forward 5'-CCGGAGAGGAGACTTCACAG-3', reverse 5'-

GAGCATTGGAAGTTGGGGTA -3', 428 bp product; glyceraldehyde 3' phosphate dehydrogenase (Gapdh): forward 5'-ACCACAGTCCATGCCATCAC-3', reverse 5'TCCACCACCCTGTTGCTGTA-3', 452 bp product). For Gapdh, samples were subjected to 21 cycles of denaturation (94/C, 30 s), annealing (59/C, 30 s) and extension (72/C, 30 s). For Atf3 and IL6, samples were subjected to 27 cycles of amplification. Bands were detected under UV light and sizes were estimated by comparison to a NX174 RF DNA Hae III digest DNA ladder (ABgene) or a 100 bp ladder (Invitrogen). Densitometric analysis was performed using Imagemaster 1D Prime, version 3.0 (GE Healthcare).

Quantitative PCR (QPCR) was performed using a 7500 Real-Time PCR System (Applied Biosystems). A master-mix containing (per reaction) 12.5 : 1 Sybr-Green Jump Start Taq Readymix (Sigma-Aldrich) and 5 : l oligonucleotides (5 pmol each of forward and reverse primers) was aliquoted into Optical 96-well reaction-plates (Applied Biosystems), and the cDNA template added (7.5 : 1, 1/15 dilution in Milli-Q filtered water). PCR conditions for all primer pairs were 50/C for $2 \mathrm{~min}$, 95/C for $10 \mathrm{~min}$, followed by 40 cycles of 95/C for 15 s and 59/C for 60 s. Following QPCR, a dissociation curve analysis was performed to check for aberrant amplification products. QPCR analysis of Gapdh was performed in each 96-well plate as an endogenous control and the relative quantitation protocol was used. Primers for QPCR were as follows: Atf3 (accession no. NM_012912): forward 5'-GAGCGAAGACTGGAGCAAAA-3', reverse 5'-AAGGTGCTTGTTCTGGATGG-3', 181 bp product; IL6 (accession no. NM_012589) : forward 5'-CCGGAGAGGAGACTTCACAG -3', reverse 5'CAGAATTGCCATTGCACAAC-3', 136 bp product; epiregulin (Ereg; accession no. 
NM_021689): forward 5'-ACTGCAGATGTGAAGTGGGC-3', reverse 5'-

GAGGAAAACGAGAATCACGG-3', 113 bp product); leukaemia inhibitory factor (Lif; accession no. NM_022196): forward 5'-TCAACTGGCTCAACTCAACG-3', reverse 5'ACCATCCGATACAGCTCGAC -3', 128 bp product); c-Jun (accession no. NM_021835): forward 5'-GATCATCCAGTCCAGCAATG-3', reverse 5'TATTCTGGCTATGCAGTTCAG -3', 140 bp product).

\section{Western blotting}

Cardiac myocyte nuclear extracts were prepared and immunoblotted as described previously (Markou et al., 2008). Blots were probed with primary rabbit polyclonal antibodies specific for Atf3 (Santa Cruz Biotechnology Inc., Cat. no. sc-188; 1/1000 dilution) or Atf2 (Santa Cruz Biotechnology Inc., Cat. no. sc-187; 1/1000 dilution), followed with horseradish peroxidase-conjugated goat anti-rabbit immunoglobulins (DakoCytomation; 1/5000 dilution). Immunoreactive bands were detected by enhanced chemiluminescence (Santa-Cruz Biotechnology Inc.) and the bands analysed by semi-quantitative scanning densitometry (Imagemaster 1D Prime version 3.0).

\section{Chromatin immunoprecipitation (ChIP)}

Following stimulation, cardiac myocytes $\left(16 \times 10^{6}\right.$ cells per sample) were fixed in formaldehyde [1 \% (v/v) final concentration, $10 \mathrm{~min}]$. The reaction was terminated by addition of glycine (125 mM final concentration, $10 \mathrm{~min}$ ). Cells were washed with ice-cold PBS, scraped into PBS containing protease and phosphatase inhibitors [0.2 mM leupeptin, $0.01 \mathrm{mM}$ trans-epoxy-succinyl-L-leucylamido-(4-guanidino)-butane (E64), $5 \mathrm{mM}$ dithiothreitol, $0.3 \mathrm{mM}$ phenylmethylsulphonyl fluoride, $0.002 \mathrm{mM}$ microcystin] and collected 
by centrifugation (3,000 g, 4/C, 5 min). Cells were lysed in 0.5 ml Buffer A [50 mM Tris$\mathrm{HCl} \mathrm{pH}$ 8.0, 2 mM EDTA, 0.1\% (v/v) NP40, 10\% (v/v) glycerol] supplemented with protease and phosphatase inhibitors (15 min). Nuclei were pelleted (3,000 g, 4/C, 5 min), resuspended in 200 : l Buffer B [50 mM Tris-HCl pH 8.0, 1\% (w/v) SDS, 5 mM EDTA] and the DNA was sheared into 200-800 bp fragments by sonication [5 × $30 \mathrm{sec}$, 4/C, amplitude $30 \%$ (Sonics Vibra-Cell ${ }^{\mathrm{TM}}$ sonicator with a $2 \mathrm{~mm}$ probe) followed by $2 \mathrm{~min}$ recovery in icewater]. Following centrifugation (4,000 g, 4/C, $5 \mathrm{~min})$, the supernatants were taken. A volume (35: 1) was reserved to assess the input and the remaining sample diluted 1/10 in RIPA buffer [50 mM Tris-HCl pH 8.0, 0.5\% (v/v) NP40, 200 mM NaCl, 0.5 mM EDTA]. Samples were precleared with protein A-Sepharose $(20: 1$ of $50 \%(\mathrm{v} / \mathrm{v})$ suspension in RIPA buffer; $15 \mathrm{~min}$ ) then incubated without (controls) or with 10 : g Atf3 rabbit polyclonal antibodies (Santa Cruz Biotechnology Inc., Cat. no. sc-188X) with rotation (4/C, overnight). Protein A-Sepharose was added [100 : l; 50\% (v/v) suspension in RIPA buffer containing 1 : g/ml sonicated salmon sperm DNA] and samples incubated with rotation (4/C, 2 h). The beads were pelleted by centrifugation $(1,000 \times \mathrm{g}, 4 / \mathrm{C}, 3 \mathrm{~min})$ and washed (4/C, $3 \mathrm{~min}$, with gentle mixing by rotation) in $1 \mathrm{ml}$ high salt buffer $[20 \mathrm{mM}$ Tris- $\mathrm{HCl} \mathrm{pH}$ 8.0, 0.1\% (w/v) SDS, 1\% (v/v) NP40, 2 mM EDTA, 500 mM NaCl] followed by 10 mM Tris-HCl pH 8.0 containing 1 mM EDTA. Immune complexes were eluted (10 min, 65/C) in $250:$ l elution buffer [10 mM Tris-HCl pH 8.0, 1 mM EDTA, 1\% (w/v) SDS], samples were centrifuged (200 g, 1 min) and supernatants collected. The elution procedure was repeated and the supernatants pooled. Crosslinks in input and immunoprecipitated samples (500:1) were reversed by incubation (65/C, overnight) with $\mathrm{NaCl}$ (0.2 M final concentration). Samples were incubated (5 min, 4/C) with $500: 1$ phenol:chloroform:isoamyl alcohol (25:24:1, pH 8.0) and the phases were separated by centrifugation (15,300 g, 4/C, $10 \mathrm{~min})$. The upper 
aqueous phases were retained and DNA precipitated by incubating with $500: 1$ isopropanol (-80/C, 3 h). Following recovery by centrifugation (15,300 g, $\left.10 \mathrm{~min}, 4^{\circ} \mathrm{C}\right)$, DNA was washed [70\% (v/v) ethanol] and resuspended in $25: 1$ Milli-Q water for subsequent PCR. PCR reactions (2 : l DNA in 20 : l final volume) were performed in $1 \times$ Buffer IV® $(A B$ Gene, 25 : l) containing Taq polymerase (1 U), dATP, dCTP, dGTP and dTTP (0.2 mM each) and 50 pmol primers. Promoter-specific primers for rat IL6 were: forward, 5'-TGCTCAAGTGCTGAGTCACT-3'; reverse 5'-AGACTCATGGGAAAATCCCA-3'). PCR amplification conditions (32 cycles) were: denaturing, 95/C, 45 s; annealing, 52/C, 45 s; extension 72/C, 1 min. The resulting RT-PCR products were analysed by ethidium bromide-agarose gel electrophoresis and the bands captured under UV illumination.

\section{Production and preparation of adenoviruses}

Replication-deficient adenoviruses expressing full-length rat Atf3 antisense RNA (AS-Atf3) or shRNA for Klf2 were prepared using the AdEasy ${ }^{\mathrm{TM}}$ XL Adenoviral Vector System (Stratagene). For Atf3, the coding sequence was isolated by PCR from rat cDNA using Pfu polymerase and primers designed to the 5' ATG start site and 3' stop codon regions. Primers were designed to include sites for restriction enzymes for insertion into the multiple cloning site of the pShuttle-CMV vector. Control samples were prepared with empty vector. For Klf2 knockdown by siRNA, pShuttle vectors were prepared containing shRNA-generating U6 promoter and annealed oligodeoxynucleotides for Klf2 shRNA. A 19 base sequence for an siRNA-generating construct against Klf2 (5'-AGACCTACACCAAGAGTTC-3') was selected using the siRNA Target Finder and Design tool (www.ambion.com/techlib/misc/siRNA_finder.html), siDESIGN center (http://www.dharmacon.com/designcenter/DesignCenterPage.aspx), and based on Lim et al., 
2005. A random control sequence was also used (5'-ATGAACGTGAATTGCTCAA-3'; targeted to luciferase (Dekker et al., 2005)). Complementary oligodeoxynucleotide pairs were synthesized (Integrated DNA Technologies) containing the sense sequence, a loop linker sequence and antisense sequence. Flanking sequences were included to generate BamH1 and HindIII restriction endonuclease overhangs on pairing for cloning into the pShuttle vector with the U6 promoter. Oligodeoxynucleotides (1 nmol each) were annealed in annealing buffer (10 mM Tris- $\mathrm{HCl} \mathrm{pH}$ 8.0, $50 \mathrm{mM} \mathrm{NaCl}, 10 \mathrm{mM} \mathrm{MgCl}$; 20 : l final volume) by heating to 95/C (5 min) then cooling to room temperature over 4 h. Following ligation into pShuttle, sequences and orientation were confirmed. The pShuttle plasmids were linearized and transformed into BJ5183-AD-1 competent cells for homologous recombination between the shuttle vector and pAdEasy-1. Recombinant pAdEasy-1 was produced in bulk in a recombination-deficient bacterial cell line (e.g. XL10-Gold®). Purified recombinant pAdEasy-1 plasmid DNA was linearised and transfected into HEK293 cells to generate recombinant adenoviruses. After 7 - 10 days, cells were collected by centrifugation (600g, $5 \mathrm{~min}$ ) and washed (10 $\mathrm{ml}$ PBS), then resuspended in $2 \mathrm{ml}$ of PBS and subjected to freeze-thaw cycles. Following centrifugation (600 g, 5 min), virus-containing supernatants were collected.

\section{Results and Discussion}

Identification of candidate IEG mRNAs likely to be subject to negative feedback regulation by IEG proteins.

We previously identified 45 IEG mRNAs upregulated in cardiac myocytes by ET-1 
(100 nM) within 30 min of stimulation (i.e. early IEGs) (Cullingford et al., 2008b). To identify IEG mRNAs which may be under negative feedback control by other IEG proteins, we selected mRNAs which were maximally upregulated at 0.5 - $1 \mathrm{~h}$ but whose expression decreased by 2 h (Table 1). Since cycloheximide inhibits the translation of negative feedback IEG proteins, any IEG mRNAs which are subject to negative feedback by these proteins should exhibit enhanced expression in the presence of cycloheximide, particularly as the response decays (i.e. at $2 \mathrm{~h}$ ). For 22 of the 31 mRNAs selected, the increase in expression induced by ET-1 was further enhanced by cycloheximide (20: M) by at least 5-fold, with an enhancement of $>10$-fold for activity regulated cytoskeletal-associated protein (Arc), Atf3,

Fig. 2 cholesterol 25-hydroxylase (Ch25h), early growth response 2 (Egr2), epiregulin (Ereg), cFos, immediate early response 2 (Ier2), IL6, c-Jun, Krüppel-like factor 2 (Klf2) and Lif (Fig. 2). Of these, Atf3 negatively regulates its own expression (Wolfgang et al., 2000) and suppresses expression of IL6 induced in macrophages by lipopolysaccharide (Gilchrist et al., 2006). Klf2 is also implicated in negative regulation of IEG expression (Amit et al., 2007). We therefore focused on the potential role of Atf3 and Klf2 in termination of IEG expression.

\section{Table 1.}

Early IEGs upregulated by ET-1 in cardiac myocytes. Data from Cullingford et al. 2008b were mined to identify early IEGs whose mRNAs were upregulated within $0.5 \mathrm{~h}$ of stimulation with ET-1 (100 nM), with maximal increases in expression at 0.5 - $1 \mathrm{~h}$ and significant decreases in expression by $2 \mathrm{~h}$. Data were collated to present the fold stimulation (relative to unstimulated controls) for cardiac myocytes exposed to ET-1 for $0.5,1$ or $2 \mathrm{~h}$, or to ET- 1 for 1 or $2 \mathrm{~h}$ in the presence of 20: M cycloheximide (CX). The increase in expression of Group A mRNAs by ET1 at 2 h was enhanced $>10$-fold by cycloheximide. Group B mRNAs exhibited a lesser 
enhancement. Within each group, IEGs are listed alphabetically. Results are means for $n=3$ (ET-1 0.5 h; CX+ET-1, 1 or 2 h), n=6 (ET-1 2 h) or n=8 (ET-1, 1 h).

\begin{tabular}{|c|c|c|c|c|c|}
\hline Gene symbol & $\begin{array}{l}\text { ET-1 } \\
0.5 \mathrm{~h}\end{array}$ & $\begin{array}{l}\text { ET-1 } \\
1 \mathrm{~h}\end{array}$ & $\begin{array}{l}\text { ET-1 } \\
2 \mathrm{~h}\end{array}$ & $\begin{array}{c}\text { CX+ET-1 } \\
1 \mathrm{~h}\end{array}$ & $\begin{array}{c}\text { CX+ET-1 } \\
2 \mathrm{~h}\end{array}$ \\
\hline \multicolumn{6}{|l|}{ Group A } \\
\hline Arc & 7.4 & 5.4 & 1.7 & 18.8 & 19.7 \\
\hline Atf3 & 4.0 & 10.6 & 2.8 & 24.7 & 36.6 \\
\hline Ch25h & 8.5 & 9.2 & 1.3 & 18.6 & 23.1 \\
\hline Egr2 & 12.7 & 8.5 & 1.4 & 25.2 & 42.1 \\
\hline Ereg & 2.0 & 3.1 & 1.3 & 5.1 & 15.4 \\
\hline c-Fos & 27.9 & 9.8 & 1.3 & 52.2 & 67.4 \\
\hline Ier2 & 5.3 & 3.4 & 1.7 & 23.2 & 29.4 \\
\hline Il6 & 4.6 & 5.6 & 2.4 & 22.1 & 53.4 \\
\hline c-Jun & 2.8 & 2.6 & 1.2 & 15.0 & 20.6 \\
\hline Klf2 & 3.5 & 3.2 & 1.0 & 8.7 & 13.3 \\
\hline Lif & 3.8 & 4.9 & 2.6 & 12.0 & 26.2 \\
\hline \multicolumn{6}{|l|}{ Group B } \\
\hline Btg2 & 4.7 & 6.1 & 2.8 & 13.4 & 15.7 \\
\hline Cyr61 & 4.2 & 5.9 & 3.7 & 19.7 & 15.7 \\
\hline Dusp1 & 4.0 & 3.1 & 2.4 & 12.0 & 16.5 \\
\hline Egr1 & 4.6 & 4.5 & 1.0 & 6.1 & 7.6 \\
\hline Has2 & 2.5 & 7.5 & 2.4 & 5.4 & 9.8 \\
\hline Junb & 4.1 & 1.7 & 1.9 & 9.3 & 8.9 \\
\hline Klf4 & 2.0 & 3.6 & 2.7 & 5.1 & 6.4 \\
\hline Klf6 & 2.4 & 4.2 & 2.1 & 7.5 & 11.8 \\
\hline Nfil3 & 2.2 & 3.4 & 2.9 & 5.0 & 9.4 \\
\hline Nfkbiz & 2.3 & 3.0 & 2.3 & 10.7 & 17.7 \\
\hline Nr4a1 & 13.6 & 17.5 & 3.7 & 22.4 & 28.9 \\
\hline $\mathrm{Nr} 4 \mathrm{a} 2$ & 3.7 & 5.1 & 1.4 & 10.4 & 13.5 \\
\hline Nr4a3 & 8.4 & 26.0 & 13.8 & 43.3 & 65.5 \\
\hline Phlda1 & 2.6 & 6.2 & 4.1 & 5.2 & 10.9 \\
\hline Plk2 & 2.4 & 3.5 & 1.9 & 6.3 & 6.9 \\
\hline Ptgs2 & 5.1 & 10.6 & 3.4 & 19.3 & 31.1 \\
\hline Rgs2 & 2.9 & 5.1 & 3.5 & 4.3 & 6.1 \\
\hline Slc25a25 & 3.3 & 3.4 & 1.9 & 7.0 & 15.7 \\
\hline Tnfaip3 & 2.5 & 2.4 & 1.6 & 7.1 & 14.0 \\
\hline Zfp36 & 5.8 & 2.8 & 2.3 & 14.0 & 16.8 \\
\hline
\end{tabular}

Regulation of expression of Atf3 and IL6 in cardiac myocytes. 
$1(100 \mathrm{nM})$ promoted a very rapid (within $15 \mathrm{~min}$ ) and potent increase in Atf3 mRNA expression in cardiac myocytes, with maximal expression at $\sim 0.5 \mathrm{~h}$ (Fig. 3A). An increase in protein expression was detected within $1 \mathrm{~h}$ of stimulation (data not shown). In a previous microarray study, we also detected simultaneous increases in expression of Atf3 and IL6 in cardiac myocytes by $\mathrm{H}_{2} \mathrm{O}_{2}$ (as an oxidative stress) (Clerk et al., 2007c). The upregulation of Atf3 in response to $0.2 \mathrm{mM} \mathrm{H}_{2} \mathrm{O}_{2}$ (Fig. 3B) was delayed relative to that induced by ET-1, with maximal expression of the mRNA at $1-2 \mathrm{~h}$ and maximal protein expression at $\sim 2 \mathrm{~h}$ (data not shown). IL6 mRNA expression was rapidly increased by either ET-1 (Fig. 3C) or $\mathrm{H}_{2} \mathrm{O}_{2}$ (Fig. 3D) with similar kinetics for upregulation as Atf3 (Fig. 3, A and B). However, downregulation of IL6 mRNA appeared to be more rapid than that of Atf3 mRNA with almost complete attenuation of the response to ET-1 within $1 \mathrm{~h}$.

To determine whether the increase in Atf3 expression induced by ET-1 downregulates the increase in expression of IL6 in cardiac myocytes, cardiac myocytes were infected with adenoviruses encoding full-length antisense RNA to Atf3 to prevent the increase in expression of Atf3 mRNA. With this system, we obtained $~ 70 \%$ inhibition of the increase in Atf3 protein induced by ET-1 (Fig. 4A). The knockdown of Atf3 was specific since there was no effect on

Fig. 4 expression of the related transcription factor Atf2 (Fig. 4A). Consistent with the proposed role for Atf3 in inhibiting IL6 mRNA expression, knockdown of Atf3 protein by antisense RNA caused superinduction of IL6 mRNA expression by ET-1 (Fig. 4B). We hypothesized that other IEG mRNAs may be subject to regulation by Atf3 in a similar manner as IL6. Of the IEGs we identified (Table 1), Ereg and Lif showed the most similar pattern to IL6 for increased expression by ET-1 and enhancement of expression by cycloheximide (Fig. 2). Interestingly, of the genes tested, Atf3 antisense RNA enhanced the increase in expression of Ereg (Fig. 4C) and Lif (Fig. 4D), but not c-Jun (Fig. 4E), c-Fos or Ier2 (data not shown). 
An Atf3 consensus sequence has been identified in the mouse IL6 promoter (Gilchrist

Fig. 5 et al., 2006). A similar sequence is present in the rat IL6 promoter (Fig. 5, A and B). To determine whether Atf3 may exert a direct negative regulatory effect on IL6 transcription by binding to this sequence, we used chromatin immunoprecipitation (ChIP) with antibodies to Atf3 to isolate DNA fragments associated with the protein and performed RT-PCR across the putative binding site in the IL6 promoter (Fig. 5B). ET-1 did indeed increase the association of Atf3 with the IL6 promoter at $1 \mathrm{~h}$ (Fig. 5C), indicating that Atf3 acts directly on the IL6 promoter to downregulate its mRNA expression.

Regulation of Klf2 and its potential role in downregulating IL6 expression.

Of the other IEGs in our selected group, Klf2 also negatively regulates IEG mRNA expression (Amit et al., 2007). Like Atf3, expression of Klf2 mRNA is detected very rapidly (within $15 \mathrm{~min}$ ) with maximal expression at 30 min and expression levels decline thereafter (Cullingford et al., 2008a). To investigate the role of Klf2 in downstream signalling, cardiac myocytes were infected with adenoviruses encoding shRNA for siRNA knockdown of Klf2 expression prior to stimulation with ET-1. We obtained $~ 56 \%$ inhibition of Klf2 mRNA

Fig. 6 expression in the absence of any effect on the related protein Klf6 (Fig. 6A). Interestingly, knockdown of Klf2 enhanced the increase in expression of IL6 (Fig. 6B) or Ereg (data not shown) induced by ET-1 in the absence of any effect on Ptgs2 (cyclooxgenase 2). Both IL6 (Fig. 5A) and Ereg promoter regions contain consensus binding sites for Klfs. It remains to be determined whether Klf2 directly binds to the promoters to inhibit expression of IL6 or Ereg, or if the effect may be indirect.

The role of negative feedback on IL6 expression in modulating cardiac function. 
IL6 family cytokines (which includes cardiotrophin-1 and Lif) stimulate gp130 receptors (Müller-Newen, 2003) to activate JAK/STAT signalling and signalling through the ERK5 cascade (Heinrich et al., 2003). Cardiotrophin 1 or Lif act via gp130 receptors to promote a form of cardiac myocyte hypertrophy in which sarcomeres are laid down in series rather than in parallel, resulting in myocyte elongation (Wollert et al., 1996; Nicol et al., 2001). However, serum levels of IL6 are elevated in pathological hypertrophy, and high, sustained expression of IL6 may contribute to the development of heart failure (Mann, 2003). It is therefore possible that part of the response induced by ET-1 may be mediated by IL6. However, limiting its production is probably necessary to prevent the deterioration of cardiac function associated with high level, sustained production of IL6. Thus, negative feedback modulators such as Atf3 and Klf2 are potentially key components of a system designed to facilitate the beneficial aspects of cardiac myocyte hypertrophy. Dysregulation of these systems may contribute to the development of heart failure.

\section{Summary}

Overall, our studies are consistent with Atf3 acting directly on the IL6 promoter to inhibit further transcription of IL6 mRNA following stimulation with ET-1, given that Atf3 protein binds directly to the promoter (Fig. 5) and knockdown of the protein enhances IL6 mRNA expression (Fig. 4). Klf2 also appears to operate in a negative feedback system to limit IL6 mRNA expression since its knockdown also enhances IL6 mRNA expression (Fig. 6), although further studies are required to determine whether its effects are directly mediated at the level of the IL6 promoter. Interestingly, Ereg appears to be co-regulated with IL6 with a similar pattern of expression in response to ET-1 and similar enhancement of expression by cycloheximide (Fig. 2), Atf3 knockdown (Fig. 4) or Klf2 knockdown (Fig. 5). However, for both IL6 and Ereg, other 
factors may further contribute to the downregulation of mRNA expression following the increase induced by ET-1, possibly by increasing its rate of degradation. It is interesting that ET-1 also increased expression of Zfp36 (Table 1) which is associated with regulation of mRNA stability (Carrick et al., 2004). This and other factors may be required to limit the expression of IL6, Ereg and other selected IEGs responding to stimuli such as ET-1, and ensure that they are expressed only transiently. Understanding how these early changes associated with intercellular or intracellular signalling and gene/protein expression relate to the changing environment of a cell will help us understand how a complex phenotypic response such as cardiac hypertrophy may develop in vivo and how such an initially beneficial response may deteriorate into (for the heart) cardiac failure.

\section{Acknowledgements}

This work was supported by grants from the British Heart Foundation, the NHLI Foundation and the Fondation Leducq.

\section{References}

Ambar I, Sokolovsky M. Endothelin recetors stimulate both phospholipase C and phospholipase D activities in different cell lines. Eur J Pharmacol 1993; 245:31-41.

Amit I, Citri A, Shay T, Lu Y, Katz M, Zhang R, Tarcic G, Siwak D, Lahad J, Jacob-Birsch J, Amariglio N, Vaisman N, Segal E, Rechavi G, Alon U, Mills GB, Domany E, Yarden Y. A module of negative feedback regulators defines growth factor signaling. Nat Genet 2007; 39:503-512.

Bogoyevitch MA, Glennon PE, Sugden PH. Endothelin-1, phorbol esters and phenylephrine stimulate MAP kinase activities in ventricular cardiomyocytes. FEBS Lett 1993; 317:271-275. 
Bogoyevitch MA, Glennon PE, Andersson MB, Clerk A, Lazou A, Marshall CJ, Parker PJ, Sugden PH. Endothelin-1 and fibroblast growth factors stimulate the mitogen-activated protein kinase signaling cascade in cardiac myocytes. The potential role of the cascade in the integration of two signaling pathways leading to myocyte hypertrophy. J Biol Chem 1994; 269:1110-1119. Bogoyevitch MA, Ketterman AJ, Sugden PH. Cellular stresses differentially activate c-Jun N-terminal protein kinases and extracellular signal-regulated protein kinases in cultured ventricular myocytes. J Biol Chem 1995; 270:29710-29717.

Brown JH, Del Re DP, Sussman MA. The Rac and Rho hall of fame: a decade of hypertrophic signaling hits. Circ Res 2006; 98:730-742.

Bueno OF, Molkentin JD. Involvement of extracellular signal-regulated kinases 1/2 in cardiac hypertrophy and cell death. Circ Res 2002; 91:776-781.

Carrick DM, Lai WS, Blackshear PJ. The tandem CCCH zinc finger protein tristetraprolin and its relevance to cytokine mRNA turnover and arthritis. Arthritis Res Ther 2004; 6:248-264.

Chen CC. Protein kinase C ", *, , and . in C6 glioma cells. TPA induces translocation and down-regulation of conventional and new PKC isoforms but not atypical PKC. . FEBS Lett 1993; 332:169-173.

Chiloeches A, Paterson HF, Marais R, Clerk A, Marshall CJ, Sugden PH. Regulation of Ras.GTP loading and Ras-Raf association in neonatal rat ventricular myocytes by G protein-coupled receptor agonists and phorbol ester. Activation of the ERK cascade by phorbol ester is mediated by Ras. J Biol Chem 1999; 274:19762-19770.

Clerk A, Bogoyevitch MA, Andersson MB, Sugden PH. Differential activation of protein kinase C isoforms by endothelin-1 and phenylephrine and subsequent stimulation of p42 and p44 mitogen-activated protein kinases in ventricular myocytes cultured from neonatal rat hearts. $\mathrm{J}$ Biol Chem 1994; 269:32848-32857. 
Clerk A, Gillespie-Brown J, Fuller SJ, Sugden PH. Stimulation of phosphatidylinositol hydrolysis, protein kinase $\mathrm{C}$ translocation, and mitogen-activated protein kinase activity by bradykinin in ventricular myocytes. Dissociation from the hypertrophic response. Biochem J 1996; 317:109-118.

Clerk A, Michael A, Sugden PH. Stimulation of the p38 mitogen-activated protein kinase pathway in neonatal rat ventricular myocytes by the G protein-coupled receptor agonists, endothelin-1 and phenylephrine: a role in cardiac myocyte hypertrophy? J Cell Biol 1998; 142:523-535.

Clerk A, Pham FH, Fuller SJ, Sahai E, Aktories K, Marais R, Marshall CJ, Sugden PH. Regulation of mitogen-activated protein kinases in cardiac myocytes through the small G protein, Rac1. Mol Cell Biol 2001; 21:1173-1184.

Clerk A, Aggeli I-KS, Stathopoulou K, Sugden PH. Peptide growth factors signal differentially through protein kinase C to extracellular signal-regulated kinases in neonatal cardiomyocytes. Cell Signal 2006; 18:225-235.

Clerk A, Cullingford TE, Fuller SJ, Giraldo A, Markou T, Pikkarainen S, Sugden PH. Signaling pathways mediating cardiac myocyte gene expression in physiological and stress responses. J Cell Physiol 2007a; 212:311-322.

Clerk A, Giraldo A, Sugden PH. Chemotherapeutic agents and gene expression in cardiac myocytes. Adv Enzyme Regul 2007b; 47:140-153.

Clerk A, Kemp TJ, Zoumpoulidou G, Sugden PH. Cardiac myocyte gene expression profiling during $\mathrm{H}_{2} \mathrm{O}_{2}$-induced apoptosis. Physiol Genomics 2007c; 29:118-127.

Clerk A, Sugden PH. Regulation of phospholipases C and D in rat ventricular myocytes: stimulation by endothelin-1, bradykinin and phenylephrine. J Mol Cell Cardiol 1997; 29:1593-1604. 
Clozel M, Salloukh H. Role of endothelin in fibrosis and anti-fibrotic potential of bosentan. Ann Med 2005; 37:2-12.

Cullingford TE, Butler MJ, Marshall AK, Tham EL, Sugden PH, Clerk A. Differential regulation of Kruppel-like factor family transcription factor expression in neonatal rat cardiac myocytes: effects of endothelin-1, oxidative stress and cytokines. Biochim Biophys Acta 2008a; 1783:12291236.

Cullingford TE, Markou T, Fuller SJ, Giraldo A, Pikkarainen S, Zoumpoulidou G, Alsafi A, Ekere C, Kemp TJ, Dennis JL, Game L, Sugden PH, Clerk A. Temporal regulation of expression of immediate early and second phase transcripts by endothelin-1 in cardiomyocytes. Genome Biol 2008b; 9:R32.

Dekker RJ, van Thienen JV, Rohlena J, deJager SC, Elderkamp YW, Seppen J, de Vries CJ, Biessen EA, van Berkel TJ, Pannekoek H, Horrevoets AJ. Endothelial KLF2 links arterial shear stress levels to the expression of vascular tone-regulating genes. Am J Pathol 2005; 167:609-618. Dorn GW,II, Robbins J, Sugden PH. Phenotyping hypertrophy: eschew obfuscation. Circ Res 2003; 92:1171-1175.

Gilchrist M, Thorsson V, Li B, Rust AG, Korb M, Kennedy K, Hai T, Bolouri H, Aderem A. Systems biology approaches identify ATF3 as a negative regulator of Toll-like receptor 4. Nature 2006; 441:173-178.

Heinrich PC, Behrmann I, Haan S, Hermanns HM, Müller-Newen G, Schaper F. Principles of interleukin (IL)-6-type cytokine signalling and its regulation. Biochem J 2003; 374:1-20.

Leach K, Turner D, Zhang W, Mulholland MW. Endothelin-1 stimulates c-fos mRNA expression in C6 glioma cells via MAP kinase pathway. Peptides 1999; 20:907-914. 
Lim Z, Kumar A, SenBanerjee S, Staniszewski K, Parmar K, Vaughan DE, Gimbrone MA,Jr., Balasubramanian V, Garcia-Cardena G, Jain MK. Kruppel-like factor 2 (KLF2) regulates endothelial thrombotic function. Circ Res 2005; 96:e48-e57.

MacCumber MW, Ross CA, Snyder SH. Endothelin in brain: receptors mitogenesis, and biosynthesis in glial cells. Proc Natl Acad Sci U S A 1990; 87:2359-2363.

Mann DL. Stress-activate cytokines and the heart: from adaptation to maladaptation. Annu Rev Physiol 2003; 65:81-101.

Markou T, Cullingford TE, Giraldo A, Weiss SC, Alsafi A, Fuller SJ, Clerk A, Sugden PH. Glycogen synthase kinases 3" and 3\$ in cardiac myocytes: regulation and consequences of their inhibition. Cell Signal 2008; 20:206-218.

Müller-Newen G. The cytokine reeptor gp130: faithfully promiscuous. Sci STKE 2003; 201:PE40.

Nicol RL, Frey N, Pearson G, Cobb M, Richardson J, Olson EN. Activated MEK5 induces serial assembly of sarcomeres and eccentric cardiac hypertrophy. EMBO J 2001; 20:2757-2767.

Shichiri M, Hirata Y, Nakajima T, Ando K, Imai T, Yanagisawa M, Masaki T, Marumo F. Endothelin-1 is an autocrine/paracrine growth factor for human cancer cell lines. J Clin Invest 1991; 87:1867-1871.

Sugden PH, Clerk A. Cellular mechanisms of cardiac hypertrophy. J Mol Med 1998; 76:725-746. Wolfgang CD, Liang G, Okamoto Y, Allen AE, Hai T. Transcriptional autorepression of the stress-inducible gene ATF3. J Biol Chem 2000; 275:16865-16870.

Wollert KC, Taga T, Saito M, Narazaki M, Kishimoto T, Glembotski CC, Vernallis AB, Heath JK, Pennica D, Wood WI, Chien KR. Cardiotrophin-1 activates a distinct form of cardiac hypertrophy. Assembly of sarcomeric units in series via gp130/leukemia inhibitory factor receptor-dependent pathways. J Biol Chem 1996; 271:9535-9545. 
Yin J, Lee JA, Howells RD. Stimulation of c-fos and c-jun gene expression and downregulation of proenkephalin gene expression in C6 glioma cells by endothelin-1. Brain Res Mol Brain Res 9920; 14:213-220. 


\section{Legends for figures}

FIG. 1. Model of regulation of gene expression. Various stimuli regulate the phosphorylation status of pre-existing proteins leading to transcription of IEGs and changes in mRNA stability/translation. IEG proteins may be "structural” (directly influencing cell function) or “regulatory” encoding further transcription/ translation factors. These feed back negatively to terminate IEG expression, and feed forward positively to drive second phase gene expression. Second phase genes encode further "structural" and "regulatory" proteins to modulate third phase genes etc. The cells continually adjust their responsiveness with different cell surface receptors. Cells also modulate their environment through secretion of extracellular matrix components and autocrine paracrine factors. Further stimuli feed into the cell to modulate the functional changes until eventually a new steady state is reached.

FIG 2. Upregulation of immediate early genes in cardiac myocytes by ET-1. Cardiac myocytes were unstimulated or exposed to $100 \mathrm{nM}$ ET-1 for $0.5,1$ or $2 \mathrm{~h}$ in the absence (solid circles, solid lines) or presence (open circles, dashed lines) of 20 : M cycloheximide and RNA expression assessed globally using Affymetrix rat genome 2302.0 microarrays. The data were mined from Cullingford et al., 2008b to identify IEGs with maximal expression at $0.5-1 \mathrm{~h}$, a decline in expression by $2 \mathrm{~h}$ and whose expression at $2 \mathrm{~h}$ was enhanced $>10$-fold by cycloheximide. Results are expressed relative to unstimulated controls and are means for $n=3$ ( 0.5 h), n=8 (1 h) or $n=6(2 \mathrm{~h})$ independent myocyte preparations.

FIG. 3. Regulation of expression of Atf3 and IL6 mRNA by ET-1 or $\mathrm{H}_{2} \mathrm{O}_{2}$ in cardiac myocytes. Neonatal cardiac myocytes were exposed to $100 \mathrm{nM} \mathrm{ET-1} \mathrm{(A} \mathrm{and} \mathrm{C)} \mathrm{or} 0.2 \mathrm{mM} \mathrm{H}_{2} \mathrm{O}_{2}$ (B and D) for the times indicated and RNA prepared. Expression of Atf3 mRNA (A and B) or IL6 mRNA 
C and D) was assessed by semi-quantitative RT-PCR. Representative images from a single experiment are shown for Atf3 or IL6 mRNA in the upper panels with images for the corresponding Gapdh mRNA in the centre panels. Densitometric analysis of the data are presented in the lower panels and are means \pm SEM for $n=3\left(\mathrm{H}_{2} \mathrm{O}_{2}\right)$ or $n=4(E T-1)$ independent myocyte preparations. Control PCR reactions were carried out in the absence of reverse transcriptase $(-\mathrm{RT}) . \# \mathrm{p}<0.01, * \mathrm{p}<0.001$ relative to unstimulated controls, one way ANOVA with Tukey post-hoc test.

FIG. 4. Knockdown of Atf3 expression enhances the increase in expression of IL6, Ereg and Lif (but not c-Jun) by ET-1. Cardiac myocytes were infected with "empty vector" adenoviruses as controls or with adenoviruses encoding full-length antisense RNA to Atf3 (AS-Atf3), then unstimulated or exposed to $10 \mathrm{nM}$ ET-1 for $1 \mathrm{~h}$. A, Cardiac myocyte extracts were immunoblotted with antibodies to Atf3 or Atf2. Representative images are shown in the left panel (Atf3, upper image; Atf2, lower image) with densitometric analysis of Atf3 expression in the right panel. Results are means \pm SEM for $n=3$ independent myocyte preparations. B-D, RNA was prepared and expression of IL6 (B), Ereg (C), Lif (D) or c-Jun (E) mRNAs analysed by QPCR. Results are expressed relative to unstimulated cardiac myocytes infected with empty vector viruses and are means \pm SEM for $\mathrm{n}=3$ independent myocyte preparations. ${ }^{*} \mathrm{p}<0.001$ relative to ET-1 stimulated, empty vector controls, one way ANOVA with Tukey post-hoc test.

Fig. 5. Atf3 binds directly to the IL6 promoter. A, Schematic diagram of potential transcription factor binding sites in the IL6 promoter. B, Sequence of the rat IL6 promoter. The transcriptional start is indicated in bold italics, the putative Atf/Cre consensus sequence for binding of Atf3 is in bold and outlined and the positions of two potential Sp1/Klf binding sites 
are in italics. Forward and reverse primers used for ChIP analysis are indicated in bold. C, Chromatin immunoprecipitation of Atf3 with PCR amplification of the rat IL6 promoter as indicated in B. Cardiac myocytes were unstimulated or exposed to $100 \mathrm{nM} \mathrm{ET-1}$ for $1 \mathrm{~h}$ and Atf3 immunoprecipitated (Atf3 IP). Additional control samples were exposed to ET-1 and processed in the absence of Atf3 immunoprecipitating antibodies (no Atf3 IP). RT-PCR was performed for input DNA and immunoprecipitated DNA. Representative images are shown in the left panel [immunoprecipitated (ChIP) DNA, upper image; input DNA, lower image] with densitometric analysis in the right panel. Results are means \pm SEM for $n=3$ independent preparations of myocytes. ${ }^{*} \mathrm{p}<0.001$ relative to unstimulated controls with Atf3 IP or to ET-1 no Atf3 IP, one way ANOVA with Tukey post-hoc test.

FIG. 6. Knockdown of Klf2 expression enhances the increase in expression of IL6 by ET-1. Cardiac myocytes were infected with adenoviruses for siRNA to a random protein (luciferase, Rndm) as controls or with adenoviruses for siRNA to Klf2 (siKlf2), then unstimulated or exposed to $100 \mathrm{nM}$ ET-1 for $1 \mathrm{~h}$. RNA was extracted and mRNA expression of Klf2 (A), Klf6 (B) or IL6 (C) assessed by QPCR. Results are expressed relative to Rndm unstimulated controls and are means \pm SEM for $n=3$ independent myocyte preparations. ${ }^{*} \mathrm{p}<0.001$ relative to Rndm + ET-1, one way ANOVA with Tukey post-hoc test.

\section{Key words}

Immediate early genes, interleukin 6, activating transcription factor 3, Krüppel like factor 2, epriregulin, endothelin-1, gene expression, siRNA, antisense, microarrays, chromatin immunoprecipitation, transcription factors, cycloheximide, signal propagation, cardiac myocytes. 
Clerk et al. Figure 1.

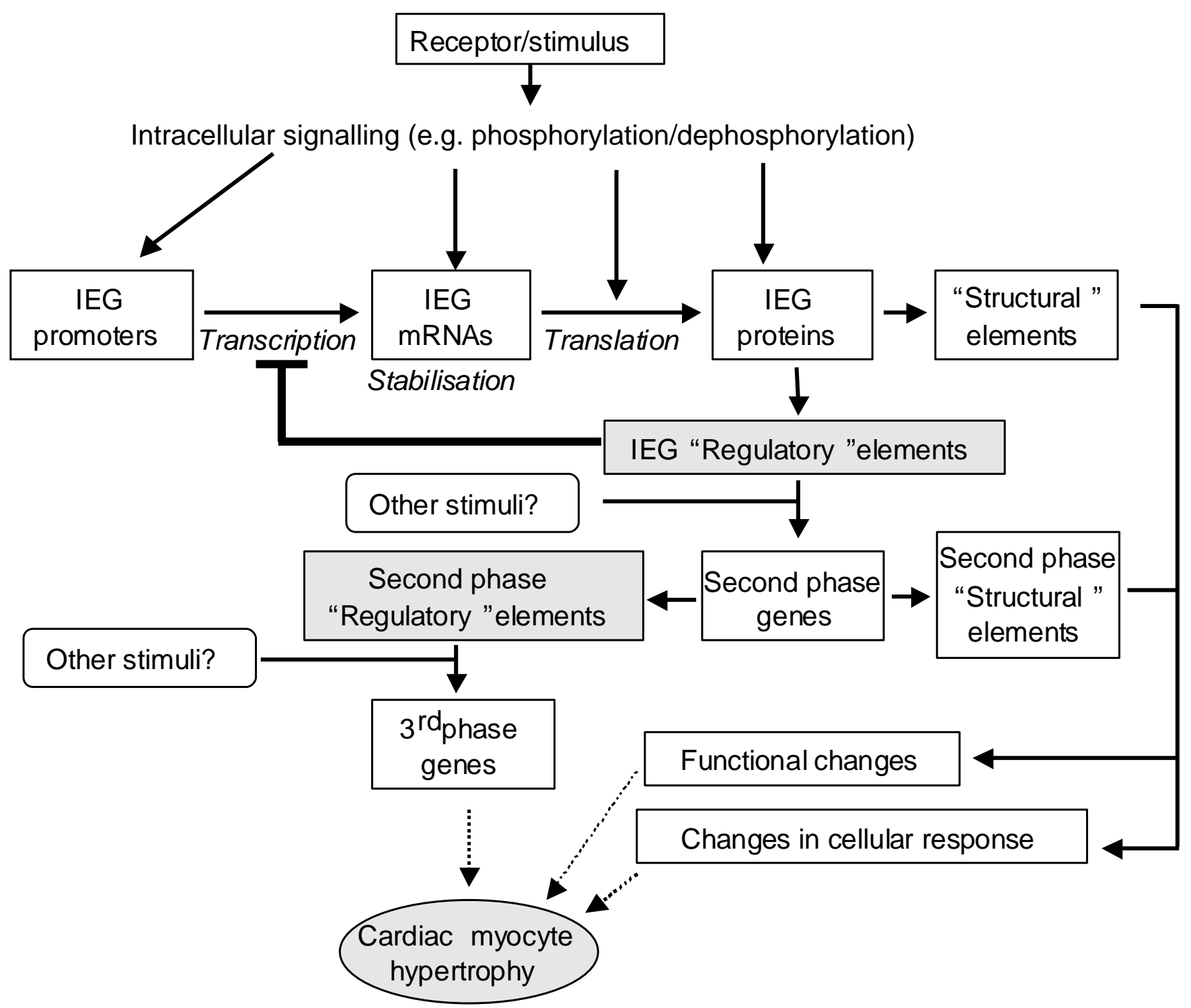


Clerk et al. Figure 2.
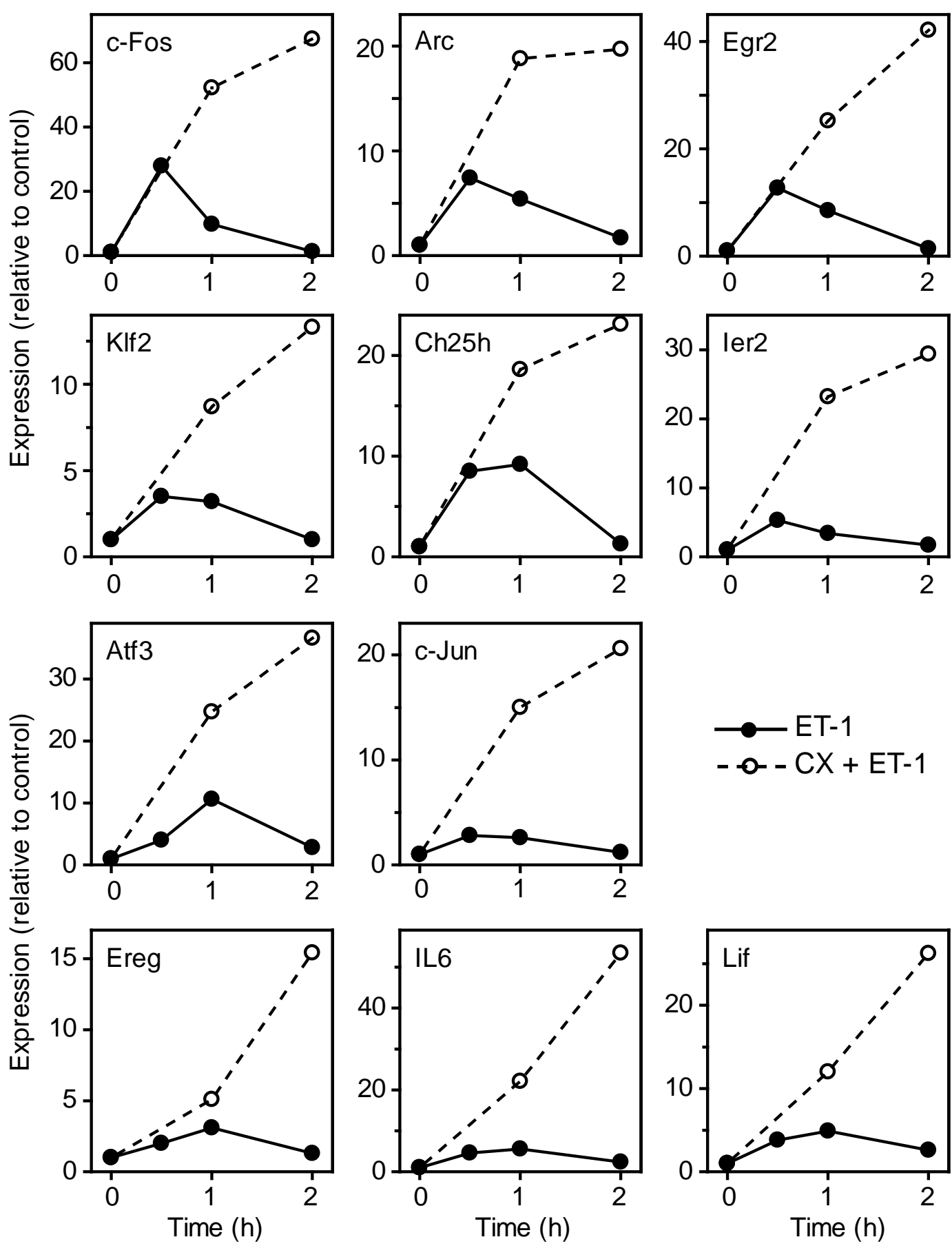
Clerk et al. Figure 3.

A

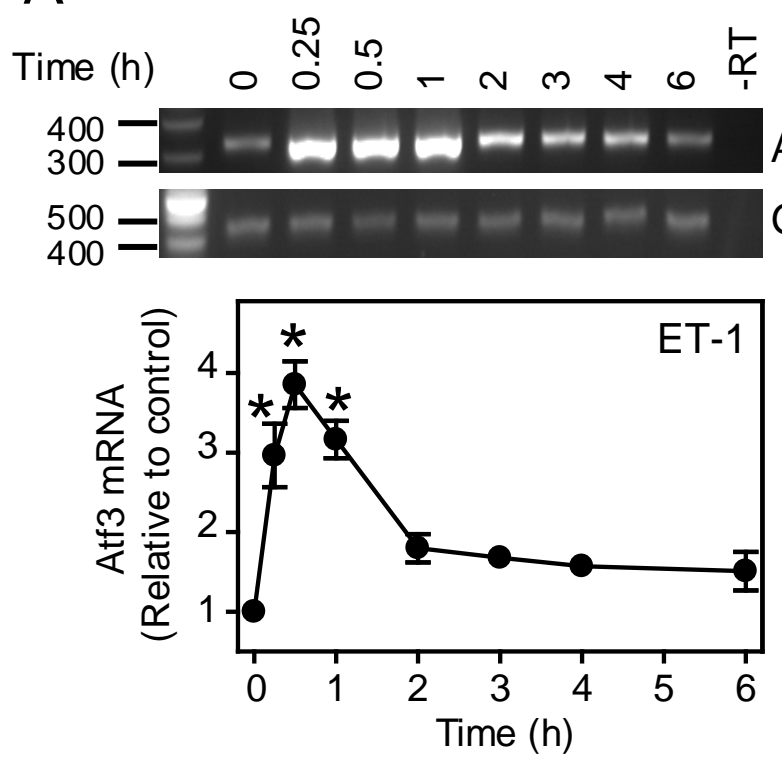

C
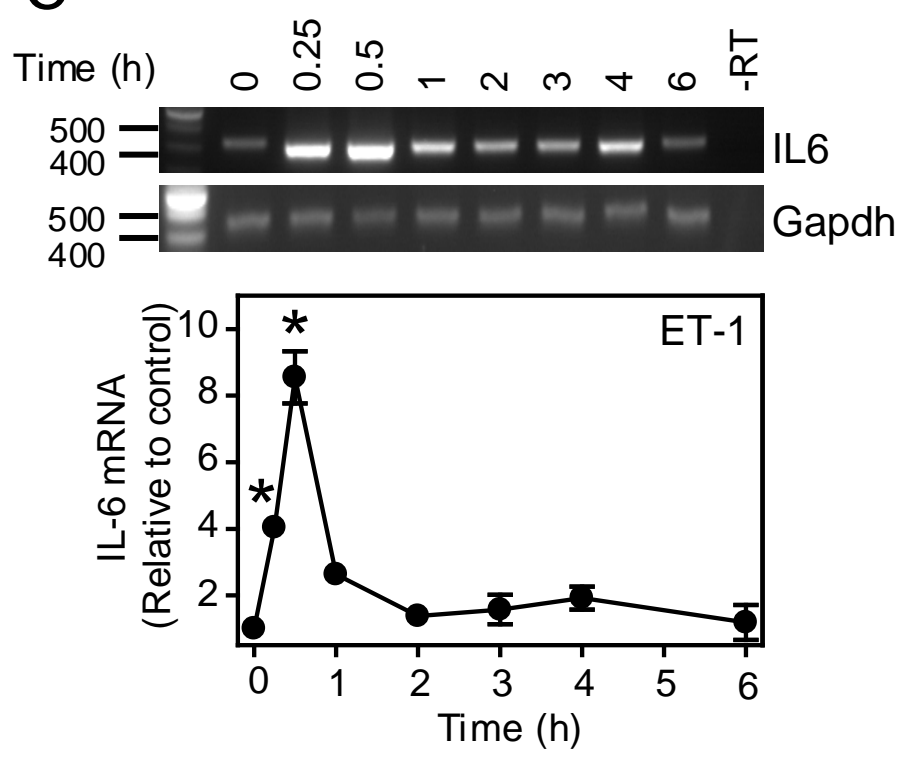
Atf3 Gapdh

\section{B}

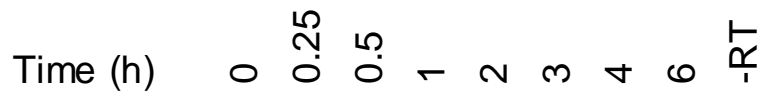

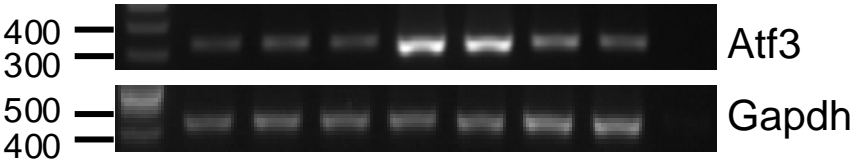

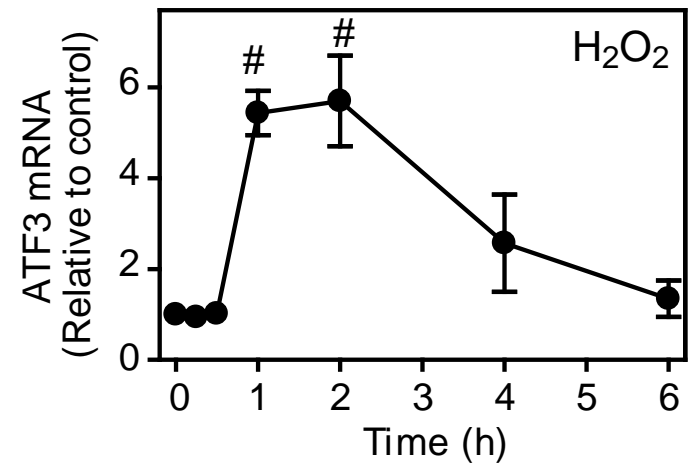

D

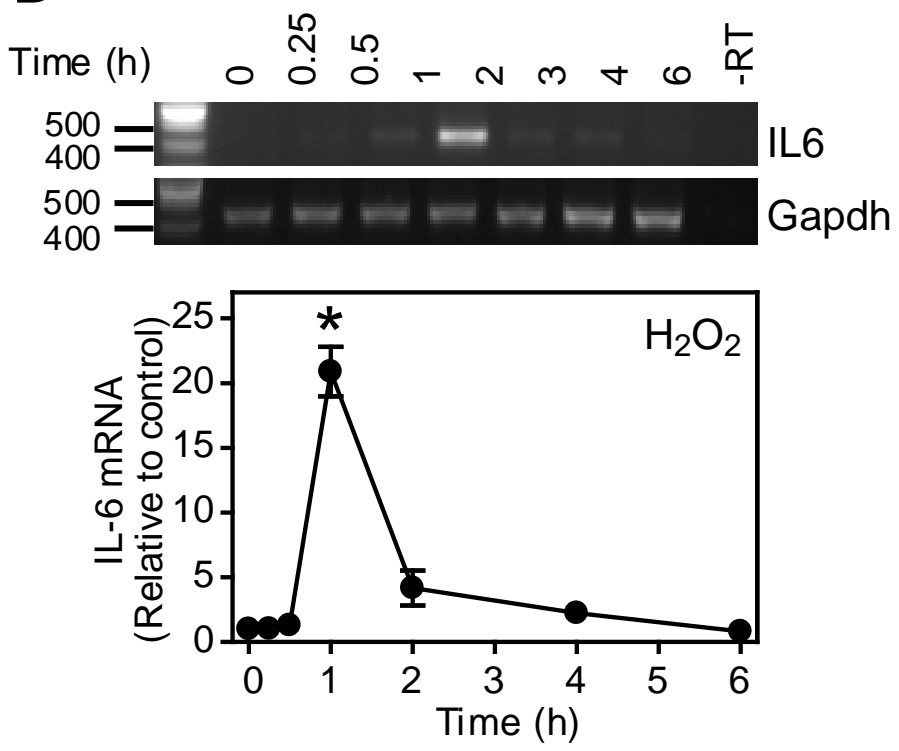


Clerk et al. Figure 4.
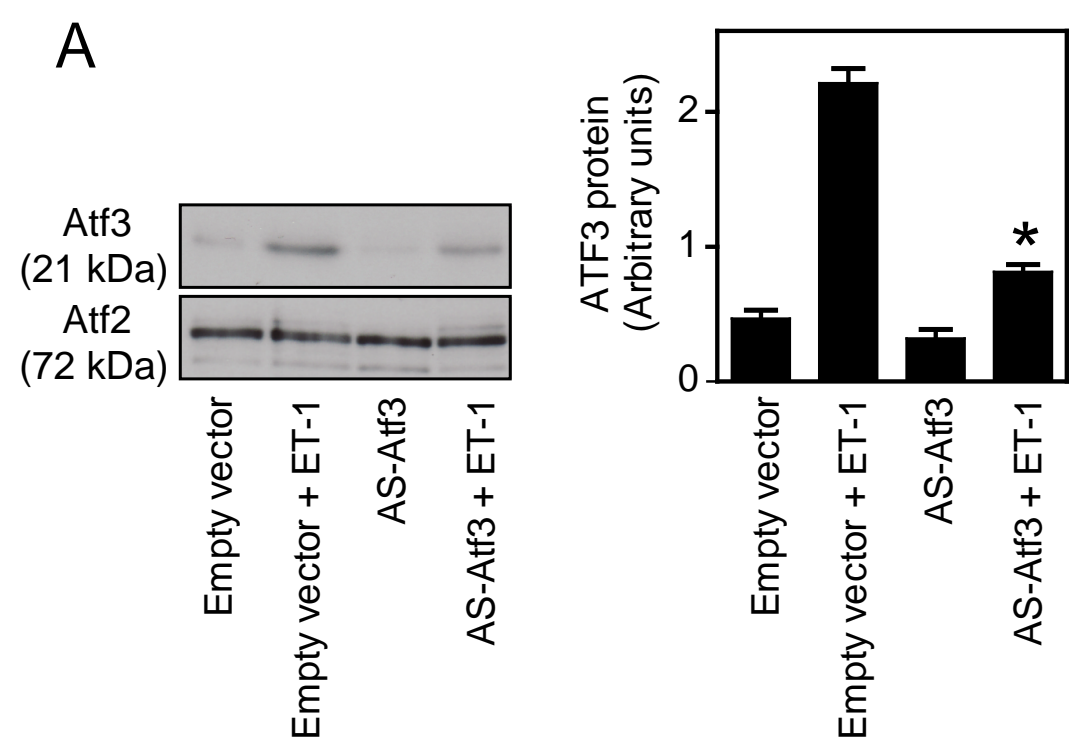

B

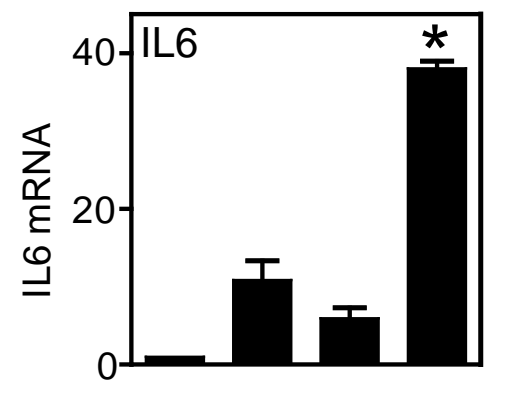

C
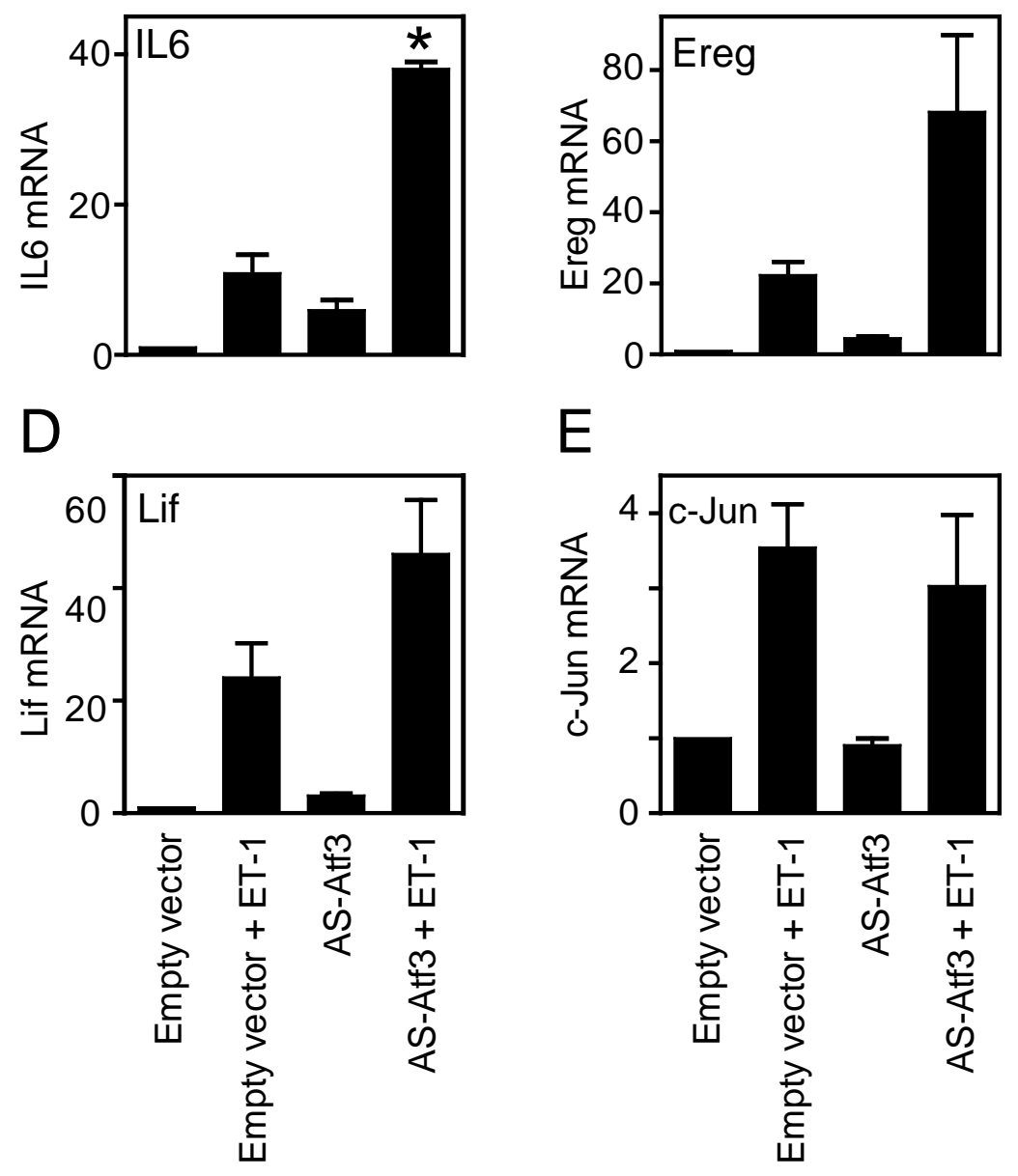

E

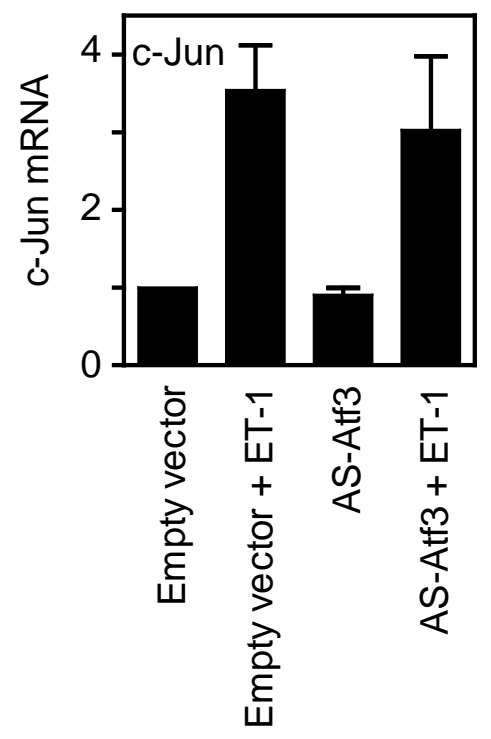


Clerk et al. Figure 5.

A

$-2 \overline{82}-\overline{-262}$
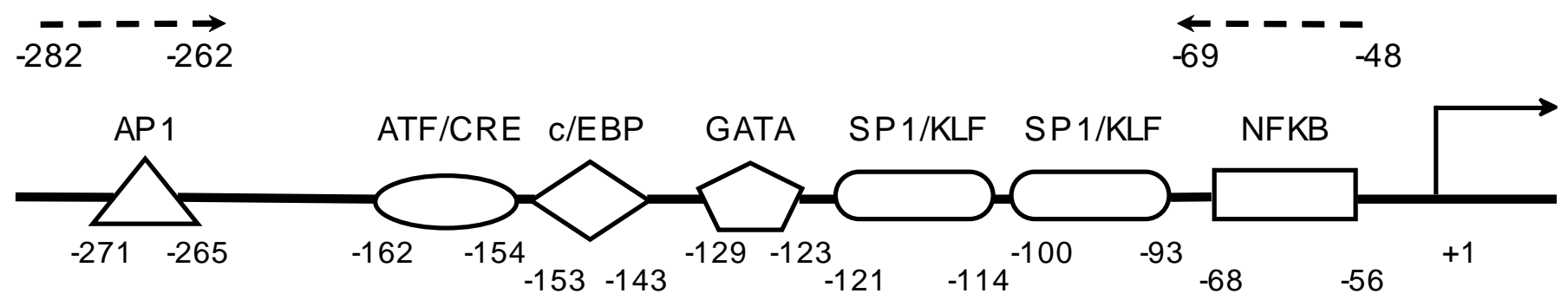

B

Rat IL6 promoter sequence (NC_005103)

Forward primer<smiles>[CH]1[CH]CC1</smiles>

GCATTTCAGTTTTTCCCCCTATCAAGTGCTCAAGTGCTGAGTCACTTTTAAAGAAAGAAAAAGA

GTGATCA GGCTTC TTAAGGATAGCC TCAAGGATGACTTAAACACACTTTCCCCCTCCTAGCTGTGATT

C TTTGGA TGCTAAA TGACGTCA TGGCCCCACC CCCACCCT CAACAAAGATTTTTATCAAATGTGGGATTTCCCATGAGTCTCAAA AGTAGA GAGTCGACTCCCAA AAATATGAGACTGGGGATGTCTGTAGC

Potential Att/Creb site

Potential Sp1/Klf site

$\bigcap_{\text {Transcriptional start site }}^{\text {Rever }}$

Reverse primer

Potential Sp1/Klf site

C
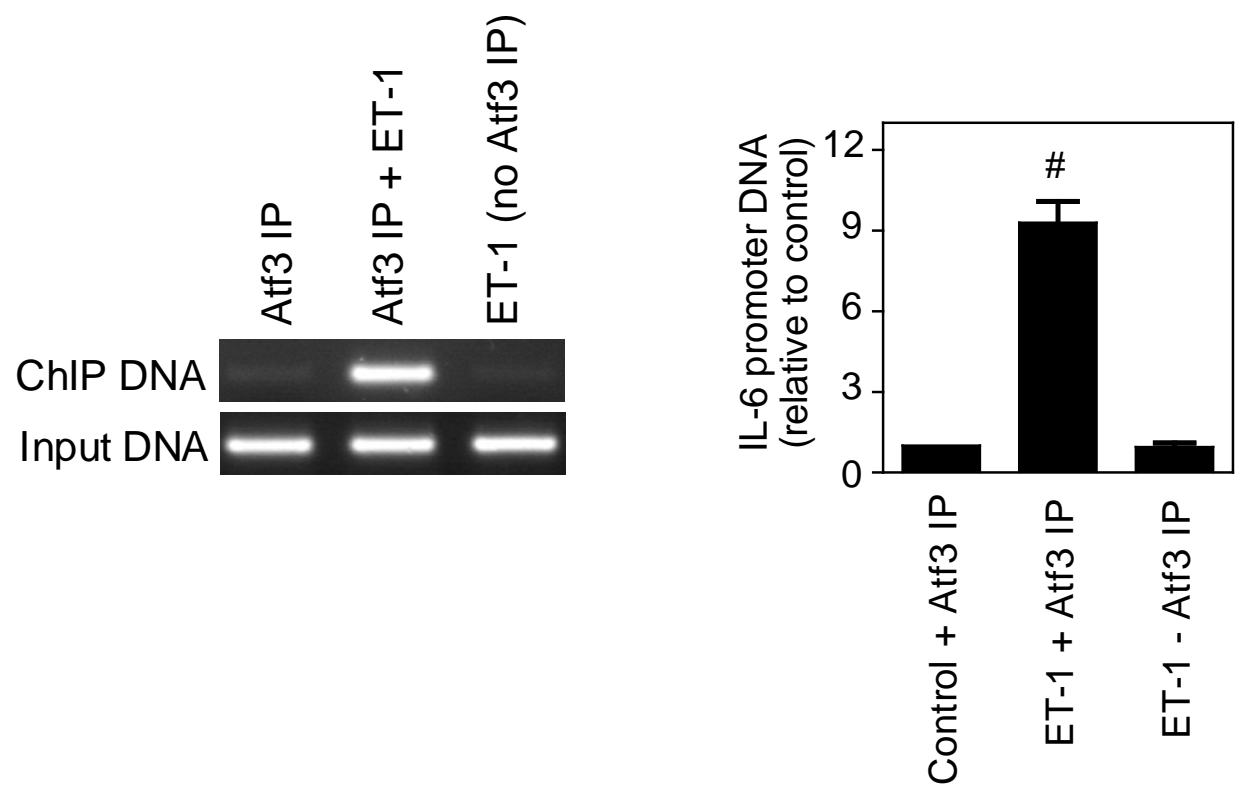
Clerk et al. Figure 6.

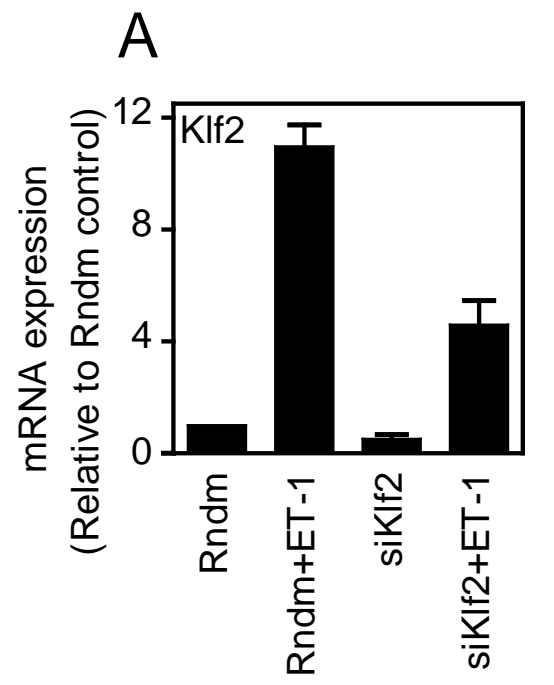

B

C
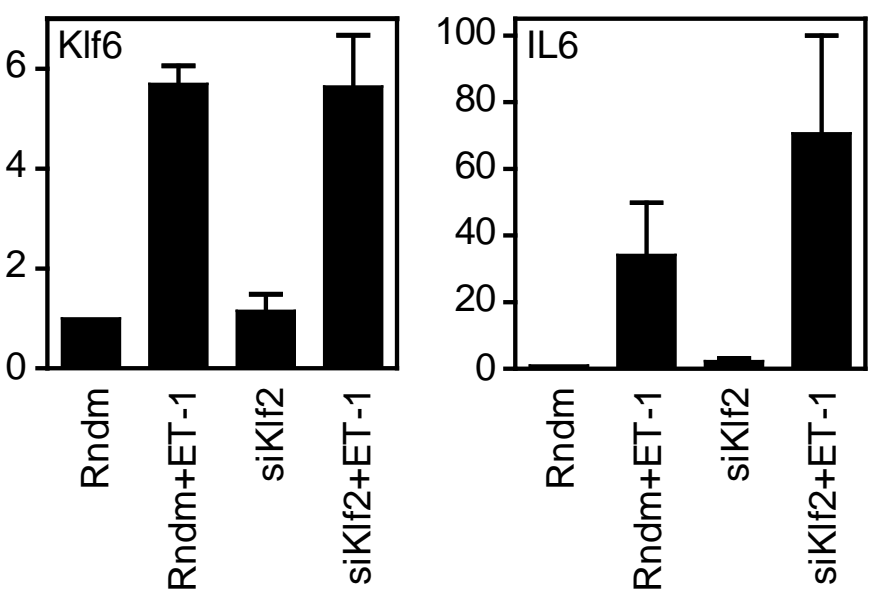